\title{
EMBEDDING MOTIVATION IN THE SELF-DIRECTEDNESS OF FIRST-YEAR TEACHER STUDENTS
}

\author{
C. du Toit-Brits* \\ Department of Curriculum Studies, Philosophy and Research \\ e-mail: charlene.dutoit@nwu.ac.za
}

\section{C-M. van Zyl}

*North-West University

Potchefstroom Campus

Potchefstroom, South Africa

\section{ABSTRACT}

This article investigated the relation between learning motivation and self-directedness in learning of first-year teacher students. Self-directed learning is characterized as one of the fastest growing areas of research in the past forty years. Self-directed learning can be regarded as an essential skill in the 21st century and it implies that the acquisition of school subject knowledge alone is not sufficient; skills such as critical thinking, resource identification and responsibility to learn should be emphasised. Furthermore, a student with a high level of self-directedness in learning can set educational objectives and also reach these objectives as well as successfully avail themselves of opportunities beyond the boundaries of formal education, which can accordingly lead to career success and economic growth. Although the value of self-directed learning can be overstated, students find it difficult to keep up with the academic pace due to the leap from secondary to tertiary education. It turns out that first-year students qualify on paper for university admission, but in fact they cannot acquire the necessary academic skills (including self-directed learning). Despite the lack of self-directed learning activities in secondary education De Lange et al. (2010) mention several factors that can affect teaching and learning (as well as self-directed learning) of a student, namely a lack of motivation. From the above statement it is evident that a lack of motivation may have an effect on a student's self-directedness in learning. Learning motivation is the driving force behind the implementation of self-directed learning activities although learning motivation is characterized as one of the most popular research dimensions in the area of self-directed learning. In an attempt to explain the above context and interpret this study, an interpretivistic qualitative research design was followed. The main research findings of this article included that learning motivation is the driving force behind self-directed learning, and therefore it enables students to learn in a self-directed manner.

Key words for index purposes: control, learning, learners, learning motivation, teachers, selfdirected learning, self-directedness, students. 


\section{INTRODUCTION}

So, why self-directed learning? Why do we or ought we research it, promote it, support and foster it? Perhaps the most basic reason lies in the fact that it is our most natural way to learn. (Guglielmino 2008, 2)

The necessity of self-directed workers in the economy is emphasised in that it has been found that a distinct relation exists between self-directedness in learning and career success (Guglielmino and Guglielmino 2000). Guglielmino and Guglielmino (2000) hold that several studies have furnished evidence that top entrepreneurs/workers achieve the highest results on the SDLRS (Self-Directed Learning Readiness Scale). High levels of self-directedness with regard to learning is an integral requirement for most careers since candidates that had achieved high marks during the SDLRS are associated with better career performance (Buhagair 2007; Dynan, Cate and Rhee 2008; Raemdonck 2006; Vandeyar 2005).

Also within education training, a South African university identified self-directed learning as a strategic priority in 2008 (Reitsma, Guglielmino and Menz 2012). Guglielmino (2013) emphasises the importance of self-directed learning in education as one of the fastest growing research areas in the past forty years and also is of opinion that self-directed learning is an essential skill in the $21^{\text {st }}$ century. Mentz (2014), along the lines of Guglielmino (2013), maintains that acquiring knowledge in school subjects only, is not sufficient for teacher students and that skills such as problem solving, critical thinking, resource identification and responsibility for own learning, need to be improved. The fore-mentioned skills are characteristic of a student with a high level of self-directedness in learning (Guglielmino 2013; Mentz 2014). Self-directedness in students' learning particularly that of teacher students' needs to be improved, since they represent South Africa's future teaching staff (Du Toit-Brits 2015; Mentz 2014). It is important for teacher students to be capable of applying self-directed learning in their own studies so that self-directed learning can be imbedded in the teacher student him/herself. To be able to effectively apply self-directed learning in a classroom, the teacher/lecturer in the classroom must be a self-directed learner him-/herself to be able to establish a classroom structure that promotes self-directed learning (Du Toit-Brits 2015). But the reality is that the first-year teacher students are from different schools (rural and urban schools), which means that their levels of learning motivation also differ. Hence it was important for us to investigate, in this article, the relation between learning motivation and selfdirectedness in learning of first-year teacher students. 


\section{GARRISON: THEORETICAL FRAMEWORK}

In this article an attempt was made to use a theoretical framework related to motivation within self-directed learning. After numerous studies of several theoretical models within which this article could be placed, it was decided to use Garrison's (1997) dimensions of self-directed learning due to the fact that Garrison sees motivation at commencement and during implementation of a self-directed learning activity as an essential feature. Although this model was developed almost two decades ago, and before the prolific onset of technology, Garrison's model is the only self-directed learning model which focus on the successfully implementation of self-management and self-monitoring during self-directed learning, where motivation is an important feature which can conceivably effect students' self-directedness in their learning. As a result of the above stated, we decided to use Garrison's theory of self-directed learning. In Table 1 Garrison's dimensions of self-directed learning are presented graphically.

Table 1: Motivation for using Garrison's dimensions of self-directed learning

$\quad$ Garrison's (1997) dimensions of self-directed learning
Dimension 1
Management (control).
Dimension 2
Self-monitoring (responsibility).
Dimension 3
Motivation (at commencement and during implementation of the learning activity).
Self-directed learning (above-mentioned three dimensions are integrated to bring about an effective approach to
self-directed learning, since these 3 dimensions can exert a direct influence on the success of self-directed
learning).

This theory was developed by Garrison with the aim of integrating cognitive, contextual and motivation dimensions with a view to facilitate self-directed learning, and is depicted in Figure 1.

Subsequently each of the dimensions of Garrison’s theory will be discussed separately.

\section{Self-management (contextual control)}

Self-management (contextual control) entails setting learning objectives and managing learning resources, and in order to apply self-management effectively to a learning process the learning environment (including people, resources, assessment and time) should be identified and managed (Alotaibi 2015; Garrison 1997). Furthermore, Garrison (1997) is of opinion that control does not focus on independence only, but also on cooperation with other individuals within a specific context. The increase in control (by means of self-management) can lead to heightened levels of responsibility and Douglas and Morris (2014) further hold that an increase in control can support and improve a student's ability to critically reflect and analyse. 


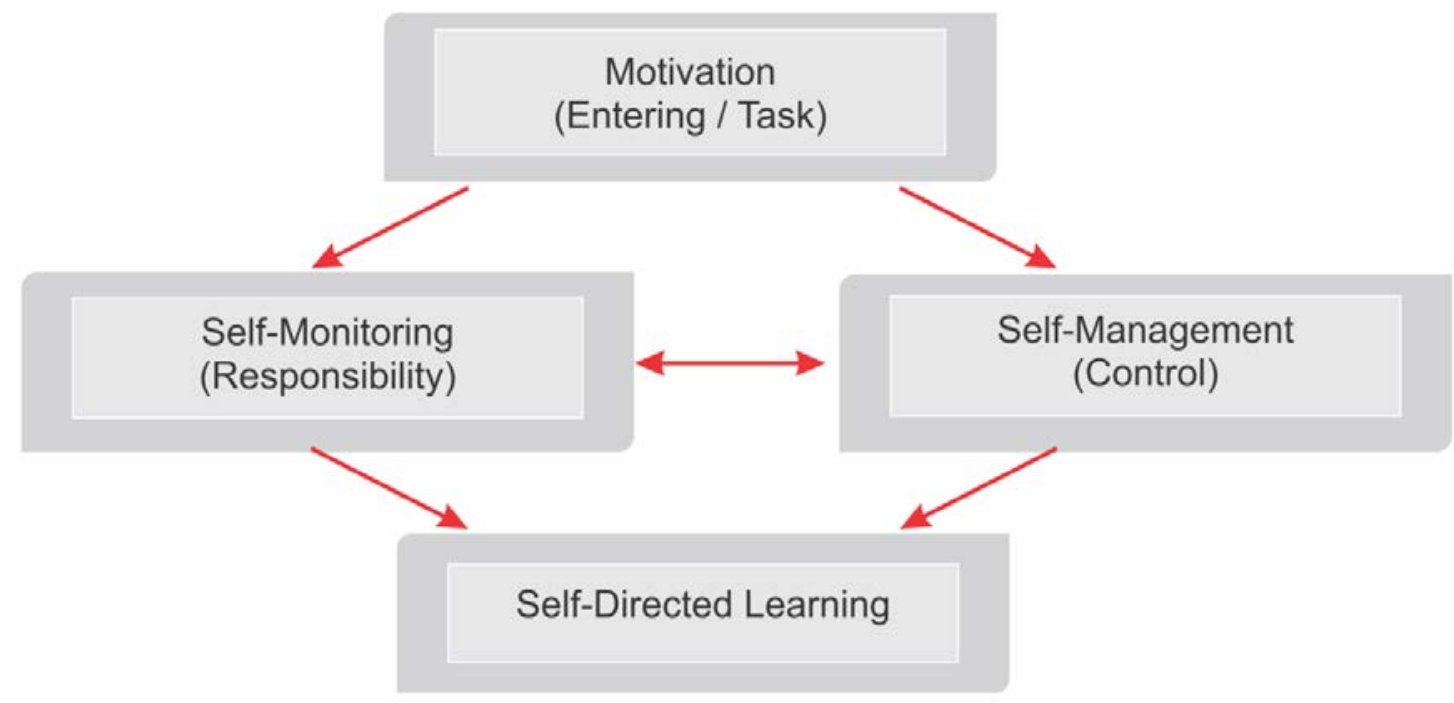

Figure 1: Garrison's dimensions of self-directed learning (taken from Garrison 1997)

Self-management cannot be separated from self-monitoring and learning motivation (Garrison 1997) and is confirmed by Candy $(1991,243)$ in the following formulation:

... increasing learner-control demands a negotiated consensus between the parties involved.

\section{Self-monitoring (cognitive responsibility) as second dimension}

As with self-management, self-monitoring entails a process during which the student him/herself takes responsibility for designing own knowledge (Garrison 1997), and we agree with Ertmer and Newby’s $(1996,12)$ enveloping definition of monitoring, namely:

Monitoring a learning act is a complex process which involves: an awareness of what one is doing, an understanding of where it fits into the established sequence of steps, and anticipation and planning for what ought to be done next.

However, it is important that Ertmer and Newby's (1996) definition needs refining with regard to what is expected from students during monitoring. Garrison (1997) and Abd-EI-Fattah (2010) are of opinion that monitoring, amongst others, entails that the student should be capable of critically reflecting on and thinking about the development of learning strategies, the construction of meaning by using constructive feedback and taking responsibility for own learning. The lecturer can support the student during self-monitoring by giving constructive feedback with a view to reach learning objectives, since self-reflection on its own cannot provide the student with teaching-learning direction (Abd-EI-Fattah 2010; Du Toit-Brits 2015). To successfully implement self-management and self-monitoring during self-directed learning, motivation is an important aspect which can possibly influence students' self-directedness in 
learning.

\section{Motivation (at commencement and during implementation of a learning activity) as third dimension}

M O T I V A T I O N is the key component in the choice of self-directed learning (Klein, Noe and Wang 2006). But why? As far back as in 1997, Garrison had already established that motivation plays an important role at commencement and during the reaching of cognitive objectives (Garrison 1997). According to Garrison’s dimensions of self-directed learning, motivation comprises two components, namely undertaking motivation and task motivation (Garrison 1997). Drawing up objectives during self-management (dimension 1) serves as the starting point for the undertaking to become motivated to tackle a learning activity, whilst task motivation refers to the degree of maintenance of motivation while implementing a learning activity (Garrison 1997). Motivation in learning, however, is influenced by several external backgrounds (contextual factors) and this motivation during the implementation of a learning activity should at all times be present and be promoted in the teaching-learning process. From the above paragraphs it is evident that self-management (contextual control), self-monitoring (cognitive responsibility) and motivation (at commencement and during implementation of a learning activity) exert influence on self-directed learning.

\section{IMPORTANCE OF MOTIVATION WITHIN SELF-DIRECTED LEARNING}

... by 2020 all learning - from elementary school through postgraduate education - will be based on the principles of self-directed learning (Knowles, as quoted by Hatcher 1997, 37).

Self-directed learning is a well-known term that continuously receives attention in the $21^{\text {st }}$ century’s learning framework and that is acknowledged as meaningful for learning experiences in a transforming world (Guglielmino 2013; Mishra, Fahnoe and Hendriksen 2013). Selfdirected learning is typified as the primary aim of teaching and serves as motivation for learning and participation in classes (Mulube and Jooste 2014). The development of self-directed learning skills can enable students to reach their educational objectives and successfully tackle opportunities beyond formal education (Breed 2013), which can possibly lead to economic growth and career success. In their research, Kan'an and Osman (2015) found that when students have self-directed learning skills at their disposal they will be capable of managing their educational needs, which in turn can lead to life-long learning. To develop the abovementioned self-directed learning skills, opportunities should be created for self-directed learning in classrooms (Du Toit-Brits 2015), and these self-directed learning opportunities can 
contribute to the promotion of metacognition. By developing self-directed learning skills students can possibly become more aware of several learning strategies that suit their learning needs (Abd-EI-Fattah 2010). Garrison (1997) and Samson (2013) are of opinion that students that learn in a self-directed manner and are motivated, can add value to the country's economic growth and development seeing that they possess good communication skills, can act in an organised manner in different learning activities and can apply self-monitoring on a continuous basis.

The term motivation is derived from the Latin word movere, which means to move (De Vos 2014; Ryan and Deci 2000). Motivation can be seen as the purposeful actualisation of motives within a specific situation where motivation emphasises the readiness or the willingness to change, depending on specific situations and time (Long 2007). Gorges and Kandler (2011) add to the definition of learning motivation in that they are of opinion that it can also be seen as a function of expected success (for instance: can I pass a specific course?) and subjective value of a learning activity (for example: do I want to register for the course and why?). De Vos (2014) and Zimmerman and Schunk (2011) further argue that learning motivation plays an essential role during teaching-learning (all the more for self-directed learning), because a) motivated students are more involved in their own learning processes than students that are not motivated; b) motivated students show more academic progress; c) motivated students achieve better results in reaching higher levels of competence; and finally d) motivated students demonstrate more satisfaction with the objectives they have reached and react positively to the teaching-learning opportunities offered to them. From the literature (Mulube and Jooste 2014; Regan 2003; Van Bommel, Boshuizen and Kwakman 2015) it can be concluded that when students demonstrate a lack of learning motivation while implementing a self-directed activity it can possibly lead to anxiety, which hinders the promotion of selfdirectedness in learning and that learning motivation is the incentive that enables students to implement a learning activity in a self-directed manner. Learning motivation can thus be seen as an essential 'aid' and 'instrument' for learning (Ginsberg 2005; McLean 2009, 7): 'Motivation is the pilot light for learning.'

Long (2007) as well as McLean (2009) emphasise the essential role learning motivation plays during teaching-learning, and further point out that learning motivation is the HEART of any teaching-learning situation. Should learning motivation be present, it can play an essential role that is necessary for reaching cognitive objectives. From the above-mentioned theoretical background it seems clear that self-directed learning has often been researched over the past decades, but self-directed learning is not always implemented effectively in the teaching practice. Reitsma et al. (2012) confirm the argument as set out above by maintaining that a gap 
exists between the changing theories of self-directed learning and the current teaching practice. These gaps can be minimised if first-year teacher students are guided to self-directedness in learning.

\section{RESEARCH METHODOLOGY}

In the research of this article an interpretivistic qualitative case study research design was followed because it aimed at investigating specific factors (learning motivation [intrinsic and extrinsic]) with a view to try to interpret and explain self-directed learning (phenomenon and opportunity to learn) of a South African university first-year teacher students. The research in this article investigated an instrumental case (learning motivation) and the relation with the phenomenon (self-directed learning or self-directedness in learning). The perceptions of firstyear teacher students in the focus area 'Self-Directed Learning' were gained with a view to ensure that meaningful data could be obtained for data analysis and interpretation.

\section{Sampling}

Nonprobability-sampling was applied and purposive sampling where the participants contributed purposefully to the research problem of this article. A Faculty of Education of a South African university was purposefully selected a) because self-directed learning had already been identified there in 2008 and b) based on the unique vision and mission that focuses on excellence in teaching-learning and research (Anon., 2013b). Two groups of participants from this Faculty of Education (of a South African university) were selected, namely seventeen (17) first-year teacher students and four (4) lecturers/researchers in the focus area 'Self-Directed Learning'. These were also the participants that were willing to partake in this study.

\section{Methods of data collection and the method of data analysis}

Semi-structured individual interviews were conducted with seventeen (17) first-year teacher students as well as with four (4) lecturers/researchers in the focus area 'Self-Directed Learning' in the Faculty of Education of a South African university. Discourse analysis was applied for analysing the research of this article seeing that data collected (semi-structured individual interviews) could be interpreted with the aim of revealing meaning (regarding the relation between learning motivation and self-directed learning) imbedded in the data. The process followed during this discourse analysis was as follows:

Step 1: semi-structured individual interviewing questions were planned prior to commencement of the interviews, and these mentioned semi-structured individual interviews were tape-recorded. 
Step 2: the tape-recordings were done verbatim by an independent specialised transcriber.

Step 3: the author was familiar with the transcripts in that tape recordings and transcripts were thoroughly controlled and compared by repeatedly reading through the transcripts and notes.

Step 4: similarities and differences between differently identified data categories were disclosed.

Step 5: identified markers were grouped.

Step 6: A pattern was established with regard to the grouping of markers

\section{ETHICAL CONSIDERATIONS}

Ethical approval was obtained from of a South African university Ethics Committee, the Dean of the Faculty of Education, for conducting semi-structured individual interviews with firstyear teacher students and lecturers/researchers in the focus area 'Self-Directed Learning'. Participation was voluntary, confidentiality and anonymity were constantly confirmed, no questions encroached upon their privacy and no participants were misled to give specific answers.

\section{TRUSTWORTHINESS}

Trustworthiness in qualitative research is extremely important and the strategies applied in this study are set out in Figure 2.

\begin{tabular}{|c|c|c|}
\hline $\begin{array}{l}\text { Credibility } \\
\text { (Completeness and } \\
\text { accuracy of data) } \\
\text { Overview: purposive sampling } \\
\text { was applied. } \\
\text { My study leader and I (as the } \\
\text { researcher) checked the general } \\
\text { purposive questionnaire and } \\
\text { selected the most suitable } \\
\text { participants from a random point. } \\
\text { Data collection: Research } \\
\text { prejudice is limited by revising raw } \\
\text { data by participants and } \\
\text { controlling by those concerned. }\end{array}$ & $\begin{array}{l}\text { Analysing ability } \\
\text { (Completeness and accuracy } \\
\text { of the analysis and } \\
\text { interpretation) } \\
\text { Processing of transcripts and } \\
\text { markers: A specialised transcriber } \\
\text { was used and I, the researcher, } \\
\text { compared each of the recordings } \\
\text { with the transcripts to ensure that no } \\
\text { data had been left out or were } \\
\text { twisted. My study leaderverified the } \\
\text { identification of my codes. } \\
\text { Verification: peer verification, } \\
\text { reflective journal and verification by } \\
\text { those concerned (study leader) }\end{array}$ & $\begin{array}{l}\text { Transparency } \\
\text { (Completeness and reporting } \\
\text { in the final document) } \\
\text { Reporting writing: significant } \\
\text { interpretations are given }\end{array}$ \\
\hline Data-collection & - Data analysis & Report \\
\hline
\end{tabular}

Figure 2: Total quality framework scheme (adapted from Roller and Lavrakas 2015) 


\section{METHODOLOGICAL ACCOUNTING OF QUALITATIVE RESEARCH INVESTIGATION}

Having studied the empirical data of this article, the author was enabled to attempt to interpret and explain the relation between learning motivation and self-directedness in learning of firstyear teacher students of a South African university. All discussions and results that follow are based on the perceptions of seventeen first-year teacher students and four lecturers/researchers in the focus area 'Self-Directed Learning' of the Faculty of Education of a South African university.

\section{Learning motivation is the impetus behind self-directed learning}

LEARNING MOTIVATION can be seen as students' POSITIVE personal mind-set and can be considered to be potential 'levers' for effective teaching and learning and, by implication, for self-directed learning. First-year teacher students and a lecturer/researcher respectively emphasised the importance of learning motivation as follows:

Motivering is, wat jou aan die gang hou, dit is wat jou, 'it keeps you going, despite of the challenges and' goedjies. Motivering is net daardie umph, of kan ek sê 'boost' wat jou vir jou gee vir die lus vir die lewe. (EOSD13: 318-321)

... jy kry nie 'n ongemotiveerde selfgerigte leerder nie. Jy weet motivering is die impetus vir alles. Van hoe jy beplan, van hoe jy monitor, vir jou drome ... (DND21: 135-137).

I must keep on working so that I can become one of, just like her, one of the good days. (EOSD8: 561-564)

So in order for you to learn yourself and to excel yourself, you need to have support, should be your parents or guardians. (EOSD10: 499-502)

From the data, it can be seen that this specific first-year student's need for external motivation to be able to learn in a self-directed manner, is superior to intrinsic learning motivation. This contradicts literature that holds that intrinsic learning motivation must take place first in order to be able to learn in a self-directed manner (Ryan and Deci 2000; Salili and Hoosain 2007). What can be concluded from the remarks of the lecturers/researchers in the focus area 'SelfDirected Learning' seems to be that intrinsic learning motivation is more important than extrinsic learning motivation and the reasons they proffer are as follows:

Ekstrinsiek beteken dus duidelik, dit beteken daar's een of ander prys of motivering van buite af en as dit nie daar is nie, dan beteken dit nie noodwendig die leerder is selfgerig nie en dit kan in 'n mate kan maar amper sê platval want studente is net gemik op die ekstrinsieke aspek van motivering terwyl intrinsieke motivering is dit' $n$ inherente dryf wat die student motiveer om aktief by leer betrokke te wees ... (DND18: 270-276)

... Jy het jouself intrinsiek motivering nodig om te sê 'okay' ten spyte van A, B en C, gaan ek verantwoordelikheid neem vir my eie leer. ... so intrinsiek by selfgerigte leer is vir my baie, baie 
meer werd as ekstrinsiek. Ekstrinsiek is egter'n pluspunt. (DND19: 369-378)

Both intrinsic and extrinsic learning motivation should be present in a student to develop en promote self-directedness in learning. The authors are also of opinion that learning motivation, and especially intrinsic learning motivation, can lead to first-year teacher students demonstrating a positive mind-set towards self-directed learning. First-year teacher students' personal mind-set can differ and this mind-set can determine how they will be controlling their motivation. In turn, the above-mentioned then also exerts an influence on self-directedness in learning, since (a) students' mind-set towards self-directed learning can differ, and that (b) students' different needs for certain kinds of learning motivation will differ; therefore, students will also fall on different positions within the motivation continuum.

It can further be presumed that learning motivation is a strong impetus behind self-directed learning (Du Toit-Brits 2015; Morrison and Premkumar, 2014; McLean 2009). For promoting self-directed learning a classroom environment is needed in which learning motivation (both extrinsic and intrinsic) is of value since learning motivation engendered by parents/guardians, and lecturers/teachers can encourage their students/learners to apply self-directed learning.

Some participants mentioned that only extrinsic learning motivation is considered valuable for implementing self-directed learning. It is alarming that should a student not be motivated extrinsically (by parents/guardians/teachers/lecturers), such a student can 'reject' self-directed learning. This type of student should feel an inherent need for intrinsic learning motivation; thus be intrinsically motivated. Hereby it is not said that extrinsic learning motivation is not important for self-directed learning, but it cannot be seen to be the ONLY kind of learning motivation, which is important for self-directed learning. Hence learning motivation can also be seen as an impetus behind self-directed learning.

An important finding is that motivation also is seen as the 'GLUE' which, regardless of life circumstances, can strengthen first-year students' self-directedness in learning and that learning motivation is inherently related to first-year teacher students' self-directedness in learning. The realisation should also prevail among lecturers that students have at their disposal different levels of motivation (the amount of motivation) and different motivation orientations (the type of motivation) and that learning motivation is a complex phenomenon. The authors are of opinion that learning motivation fulfils an important role in first-year teacher students' behaviour to implement a specific learning act, in a self-directed manner, and the following findings can therefore be made:

- that learning motivation is present in first-year teacher students when they take the 
initiative when implementing a learning activity;

- $\quad$ that first-year teacher students need to personally take responsibility for implementing a learning activity;

- $\quad$ that students' learning objectives and the learning activity should correspond with each other;

- that intrinsic learning motivation is recommended to promote students' self-directedness in learning;

- $\quad$ that learning motivation is essential during self-directed learning;

- $\quad$ that, when motivation is present in first-year teacher students, they will be more involved in their own learning processes;

- $\quad$ that, when students lack learning motivation while implementing self-directed learning activities, it can potentially lead to anxiety, which can hinder the promotion of selfdirectedness in learning;

- that first-year teacher students will tackle self-directed learning more 'voluntarily' if learning motivation is present in them;

- that lecturers' support and encouragement of their students should be meaningful for their students to be able to carry on implementing self-directed learning activities;

- that lecturers themselves should also apply the specific principles of learning motivation to lead students to self-directedness in learning;

- that the lecturer is responsible for creating a positive self-directed learning classroom climate in which learning motivation is encouraged; and

- that the lecturer should be known to be a role model who also demonstrates self-directed learning during teaching-learning activities (Du Toit-Brits 2015).

Should the lecturer motivate students and also encourage intrinsic motivation to utilise selfdirected learning opportunities, their self-directedness in learning should most probably be strengthened and the following theoretical substructure concerning the relation between learning motivation and self-directedness in learning can be depicted in Figure 3.

Concluded from Figure 3, learning motivation should be the driving force for first-year teacher students with regard to implementing self-directed learning activities, and that intrinsic learning motivation is recommended for self-directed learning, since it leads to quality learning. However, the problem is that lecturers in the lecturing halls and educational institutions often exclusively focus on the development of extrinsic learning motivation. Hence learning motivation should prevail at commencement and during implementation of self-directed 
learning activities.

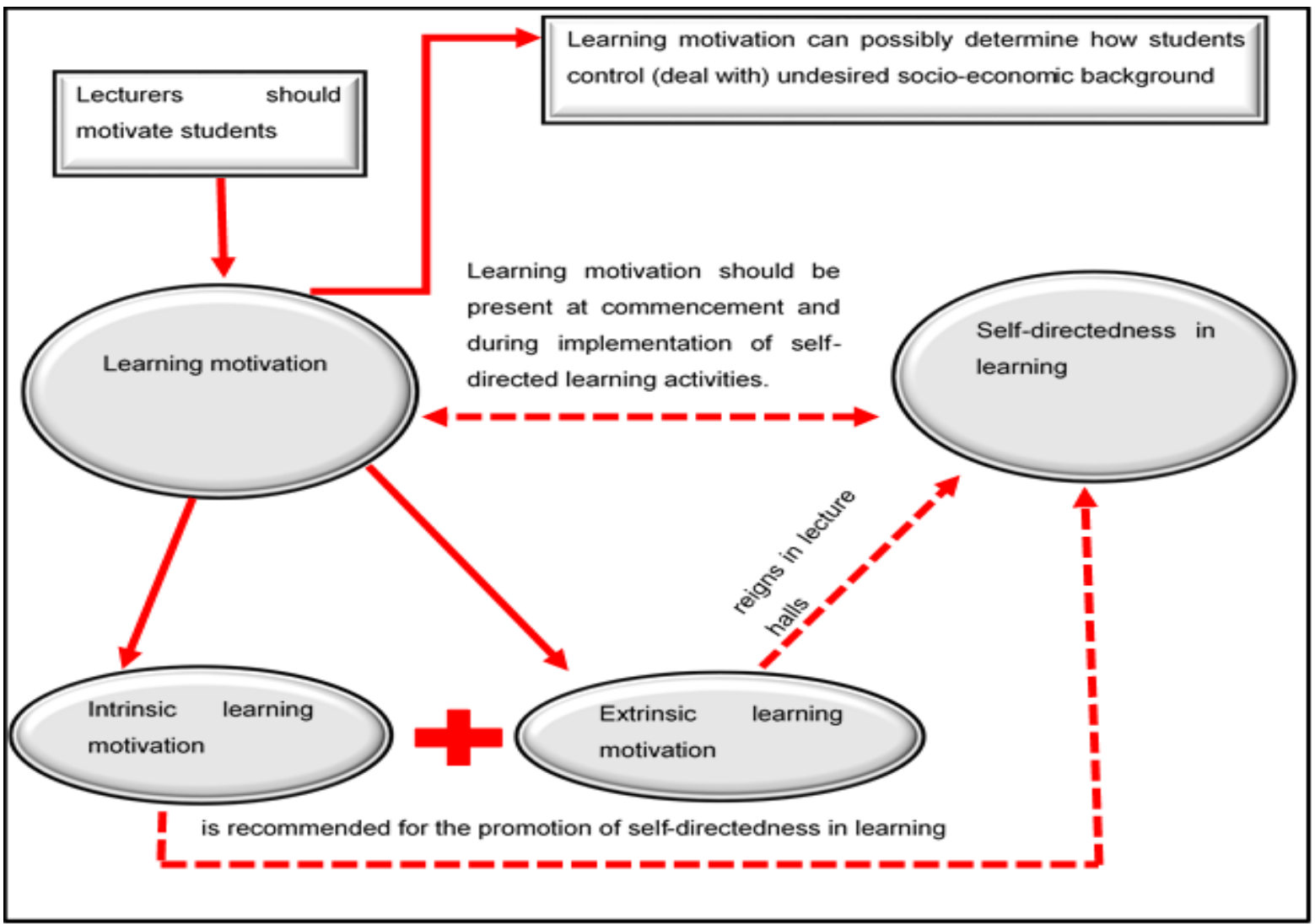

Figure 3: The theoretical substructure concerning the relation between learning motivation and selfdirectedness in learning

\section{CONCLUSION}

From this article it is clear that a relation does exist between motivation and self-directed learning. Some participants (first year teacher students of a South African university) mentioned that only extrinsic learning motivation is considered valuable for implementing self-directed learning in their learning. On the other hand, the four (4) lecturers/researchers of a South African university were of opinion that intrinsic motivation is an important factor influencing the self-directedness of students. This is in keeping with the literature. Self-directed learning could be facilitated by the adoption of intrinsic motivational factors and hindered by extrinsic motivational factors. It was also confirmed by the four (4) lecturers/researchers that intrinsic motivation is an important factor for students' willingness to partake in self-directed learning and it reflects feelings and behaviours in a student's learning environment - an environment which students may rank as high levels of instructor control. But an increase in self-directed learning is related to feelings of dissociation and dislike as well as detachment from learning 
activities in those environments, in terms of both involvement in lecture sessions and intellectual commitment and engagement with the learning material. Collectively, the findings and associated theoretical dialogues underline the significance of bearing in mind that motivation as an imperative factor influencing students' self-directedness in learning and lecturers need to consider permitting students to impact the themes of study, the progression of learning, or themes as well as procedures. Therefore, the educational choices connected to SDL are multifarious and lecturers need to attentively reflect on the unique student populations with diverse levels of motivation within each class.

Therefore, the authors are of opinion that self-directed learning rests on a self-directed learning change that needs to be a deliberate change in an aspect of who you are or who you want to be, or both (intrinsic motivation) - thus self-directed learning is self-directed motivational change in which the student is aware of the change and understands the process of change. The process of change into more intrinsically motivated and engaged self-directed students requires that students need to know themselves and recognise not only their strong points but also their flaws. Nevertheless, the absence of intrinsic motivation and inspirations is a main distress in students' willingness to participate in self-directed learning and enduring motivation is indispensable and it needs to imitate a student's willingness to learn in a more self-directed learning style, with intrinsic motivation as substructure. As described earlier, the findings of this article specify that the weakening in motivation was the key motive for some of the students to not partake in self-directed learning.

As a result, we suggested that, in order to support the students' motivation in self-directed learning, the University as well as the lecturers need to:

- $\quad$ offer self-directed learning content to students, which is appropriate and valuable to them;

- $\quad$ embrace resources in the course that encourage the self-directedness of students and students' attentiveness;

- $\quad$ embrace self-directed learning activities that pretend real-world conditions;

- $\quad$ deliver students with hands-on self-directed activities that engage them in self-directed learning;

- make yourselves available to students with sufficient response to their performance;

- $\quad$ design a self-directed learning podium that is easy to use; thus user friendly;

- design the BEd programme in such a manner that the student is gratified with the complete self-directed learning involvement;

- realise that self-directedness in learning is not automatically an instinctive characteristic, 
and that self-directed behaviours can be learned and cultivated through self-directed learning instruction;

- not demotivate students through the ineffective use of SDL in educational training programmes;

- $\quad$ realise that students need to grow in their SDL capacity maturity; and

- $\quad$ realise that self-directed learning needs to become lifelong education.

Motivation is thus significant for students in self-directed learning environments, because most students seem to begin self-directed learning for intrinsic purposes, and self-motivation is vital in such learning environments. In the learning environments of the Faculty of Education of a South African university, the most important business of a lecturer in a self-directed learning environment therefore is:

- $\quad$ to establish learning motivation need as the drive behaviour of SDL and personal learning;

- $\quad$ to establish a positive relationship between motivation, SDL and learning environment;

- to continuously increase their knowledge on SDL to be better equipped to perform their work;

- to foster motivation within each teacher student, and these students need to know that students' motivation determines, directs, and sustains what they do to learn.

Therefore. students need to learn how to learn, what to learn, when to learn, and where to learn, and to do that they have to remain wanting to learn, or relearn to want to learn. This is caution in their teacher training because one day they will have to guide their students' needs for how to learn, what to learn, when to learn, and where to learn. This is the very core of SDL, and SDL and motivation are equally indispensable for academic performance. No motivational strategies will succeed if SDL learning environment requirements are not met. Learning environment conditions for SDL need to be supportive, sincere and inspiring so that students are adequately protected in order to take risks deprived of anxiety for disparagement.

\section{REFERENCES}

Abd-EI-Fattah, S. M. 2010. Garrison's model of self-directed learning: Preliminary validation and relationship to academic achievement. Spanish Journal of Psychology 13(2): 586-596.

Alotaibi, K. N. 2015. The learning environment a mediating variable between self-directed learning readiness and academic performance of a sample of Saudi nursing and medical emergency students. Nurse Education Today 36: 249-254.

Breed, B. 2013. Exploring the promotion of self-directed learning through a metacognitive approach to 
pair programming. SA-eDUC Journal 10(2): 1-19.

Buhagair, M. A. 2007. Classroom assessment within the alternative assessment paradigm. The Curriculum Journal 18(1): 39-56.

Candy, P. C. 1991. Self-direction for lifelong learning: A comprehensive guide to theory and practice. San Francisco, Calif.: Jossey-Bass.

De Lange, N., C. Mitchell, R. Moletsane, R. Balfour, V. Wedekind, D. Pillay and T. Buthelezi. 2010. Every voice counts: Towards a new agenda for schools in rural communities in the age of AIDS. Education as Change 14(S1): S45-S55.

De Vos, J. E. 2014. 'n Leesmotiveringsprofiel van en 'n -raamwerk vir Afrikaanssprekende adolessentelesers. Potchefstroom: Noordwes-Universiteit. PhD Proefskrif.

Douglass, C. and S. Morris. 2014. Student perspectives on self-directed learning. Journal of the Scholarship of Teaching and Learning 14(1): 13-25.

Du Toit-Brits, C. 2015. Endowing self-directed learning in learning environments: Interrelated connection between students' environments and self-directed preparedness. Journal of Education Studies Special issue (2015): 32-52.

Dynan, L., T. Cate and K. Rhee. 2008. The impact of learning structure on students' readiness for selfdirected learning. Journal of Education for Business: 96-100.

Ertmer, P. A. and T. J. Newby. 1996. The expert learner: Strategic, self-regulated and reflective. Instructional Science 24: 1-24.

Garrison, D. R. 1997. Self-directed learning: Toward a comprehensive model. Adult Education Quarterly 48(1): 18-33.

Ginsberg, M. B. 2005. Cultural diversity, motivation and differentiation. Theory into Practice 44(3): 218-225.

Gorges, J. and C. Kandler. 2011. Adults' learning motivation: Expectancy of success, value, and the role of affective memories. Learning and Individual Differences 22: 610-617.

Guglielmino, L. M. 2008. Why self-directed learning. International Journal of Self-directed Learning 5(1): 1-14.

Guglielmino, L. M. 2013. The case for promoting self-directed learning in formal educational institutions. SA-eDUC Journal 10(2): 1-18.

Guglielmino, P. J. and L. M. Guglielmino. 2000. Moving toward a distributed learning model based on self-managed learning. SAM Advanced Management Journal 66(3): 36-43.

Hatcher, T.G. 1997. The ins and outs of self-directed learning. Training and development 51(2): 3439.

Kan'an, A. and K. Osman. 2015. The relationship between self-directed learning skills and science achievement among Qatari students. Creative Education 6(8): 790-797.

Klein, H. J., R. A. Noe and C. Wang, C. 2006. Motivation to learn and course outcomes: the impact of delivery mode, learning goal orientation, and perceived barriers and enablers. Personal psychology 59(3): 665-702.

Knowles, M. S. 1975. Self-directed learning: A guide for learners and teachers. Englewood Cliffs, N.J.: Cambridge Adult Education.

Long, R. 2007. The Rob Long omnibus edition of better behaviour. New York: Routledge.

McLean, A. 2009. Motivating every learner. London: Sage.

Mentz, E. 2014. Preparing pre-service teachers to support self-directed learning. http://www.p21.org/ news-events/p21blog/1477-mentz-preparing-pre-service-teachers-to-support-self-directedlearning (accessed 1 May 2015).

Mishra, P., C. Fahnoe and D. Hendriksen. 2013. Creativity, self-directed learning and the architecture of technology rich environments. Tech trends 57(1): 10-13. 
Morrison, D. and K. Premkumar. 2014. Practical strategies to promote self-directed learning in the medical curriculum. International Journal of Self-Directed Learning 11(1): 1-11.

Mulube, S. M. and K. Jooste. 2014. First-year learner nurses' perceptions of learning motivation in selfdirected learning in a simulated skills laboratory at a higher education institution. South African Journal of Higher Education 28(6): 1776-1794.

Raemdonck, I. 2006. Self-directedness in learning and career processes: A study in lower-qualified employees in Flanders. Belgium: University Gent. PhD Thesis.

Regan, J.A. 2003. Motivating students towards self-directed learning. Nurse education today 23(8): 593-599.

Reitsma, G., L. Guglielmino and E. Mentz. 2012. Faculty development to promote self-directed learning: The North-West University approach. International Journal of Self-Directed Learning 9(2): 44-51.

Ryan, R. M. and E. L. Deci. 2000. Intrinsic and extrinsic motivations: Classic definitions and new directions. Contemporary Educational Psychology 25(1): 54-67.

Salili, F. and R. Hoosain. 2007. Culture, motivation, and learning: a multicultural perspective. In Culture, motivation, and learning: A multicultural perspective, ed. F. Salili, F. and R. Hoosain, 316. Greenwich, Conn.: Information Age Publishing.

Samson, D. J. 2013. How self-directed learning works. http://www.obooko.com/obooko_business/ bookpages/business/free\%20ebook-self-directed-learning-samson-bus0024.php (accessed 27 February 2015).

Van Bommel, M., H. P. A. Boshuizen and K. Kwakman. 2015. Appreciation of a constructivist curriculum for learning theoretical knowledge by social work students with different kinds and levels of learning motivation. International Journal of Educational Research 71: 65-74.

Vandeyar, S. 2005. Conflicting demands: Assessment practices in three South African primary schools undergoing desecration. Curriculum Inquiry 35(4): 461-481.

Zimmerman, B. J. and D. H. Schunk. 2011. Self-regulated learning and performance. An introduction and an overview. In Handbook of self-regulation of learning and performance, ed. B. J. Zimmerman and D. H. Schunk, 1-12. New York: Routledge. 